examine the qualifications and continuing development of engineers throughout the world. The ultimate aim, still a long way off, is international recognition of qualifications, so that an engineer from Poland, say, can have his qualifications recognized in Ethiopia. This committee will also help to speed the exchange of ideas in the education of engineers, and should help developing countries which are setting up departments of engineering. The other project started by the federation is to examine the possibilities of a world-wide information system, for dissemination and retrieval. This committee will be collaborating with the abstract board of ICSU. The federation has also started on a more abstract project, that of drawing up an international code of conduct for professional engineers.

The general work of the federation will be financed from contributions from member countries. The special committees, on the other hand, are each charged with responsibility for finding sources of funds for their investigations. Dr Gainsborough is hoping that Unesco, OECD and other international organizations will see the federation as a body worthy of support. There seems every likelihood that this hope will be justified.

\section{No Student Power at Oxford}

\section{from our Oxford Correspondent}

IT was too much to expect the Hebdomadal Council to comment other than adversely on the petition submitted to the Privy Council for various reforms in government of the University of Oxford. One of the three chief proposals of the petition, intended to give undergraduates direct representation in university affairs, would indeed have been without precedent in many less staid institutions. In its letter to the Privy Council, the Hebdomadal Council took an optimistic view of relations within the colleges between undergraduates and senior members, and justified its rejection of the proposal because the Student Representation Council is not highly regarded by the undergraduates themselves. The argument is circular; the SRC is not even recognized by, let alone allowed to participate in, the university government. Its lack of prestige among students is a reflexion of this. But in any case, the council's dismissal of the proposition will doubtless be justified shortly by the anarchic demise of the London School of Economics whose Board of Governors has decided to admit students to certain committees (see Nature, 21\%, 699; 1968).

A second proposal in the petition is that the convocation of the university's MÂs should be made into an active forum, rather than consigned to impotence as it will be under the Franks Commission's recommendations. This proposal indeed seems "unnecessary and undesirable". As the Hebdomadal Council points out, many members of convocation live abroad, and most are too busy to attend sessions.

The rejection of the third proposal of the petition, outlined at some length in Nature $(21 \%, 500 ; 1968)$, is not so easily defended. The Hebdomadal Council does not deny that, in the disciplinary procedure of the university, the proctors act both as judges and policemen, so that there is a possibility of bias in the judgment of students' misdeeds. Yet the council (which, it is worth noting, includes proctors) announces its satisfaction with the present arrangements. The council's claim that students are made aware of their right to appeal against proctorial decisions to an independent committee is indeed true. But this has no bearing on what is requested by the petition. If the proctors confined themselves to the carrying out of petty university regulations, such as the licensing of student's cars, then the reform of proctorial procedure would scarcely be worth the attention of the Privy Council, but the Oxford proctors, unlike their Cambridge counterparts, show little reluctance to act in cases where junior members have broken the law of the land, rather than simply that of the university. The proctors' terms of reference are wide and their punishments sometimes severe, and it is only reasonable that the slightest possibility of bias should be eliminated.

Among the signatories of the petition, senior members of the university outnumber juniors by 101 to 29 . In its letter to the Privy Council the Hebdomadal Council doubts whether the request of 100 out of the 1,600 members of the congregation (the "parliament of senior members") is enough to justify discussion of major constitutional changes. Yet it is well known that few senior members attend the congregation. Important issues have been decided with less than 200 people present. Outside observers might be expected to be surprised that so great a demand still exists for new reforms 18 months after the Commission of Inquiry issued its report. It will be interesting to see how this consideration weighs with the Privy Council as it studies the petition and the reply.

\section{More Teachers}

THE latest volume of Statistics of Education, 1966 (published by HMSO, price $£ 1$ ) starts on a cheerful note, for between October 1965 and October 1966, the number of students training to be teachers in England and Wales rose by more than 12,000, bringing the total to 88,823 . This represents an increase of nearly 75 per cent over the figure of 50,942 for 1962 . In addition there were 1,308 men and 654 women in one-year supplementary or advanced courses, and courses of one year for the teaching of handicapped children also showed a marked increase for the same period. Less reassuring is the decline in the proportion of students successfully completing training in both junior and secondary courses, even though the numbers and proportions in infant/junior and junior/secondary courses increased. Another unsatisfactory trend was the fall between 1963 and 1966 in the numbers of courses for secondary school teachers and students for them.

The increase in the total teaching force from 321,000 in 1962 to 349,000 for 1966 was most striking in the colleges of education, where the number of teachers was more than doubled. A 70 per cent increase for further education establishments is also a striking feature. Up to March 31, 1966, 20 per cent of teachers in maintained primary and secondary schools were graduates-the proportions ranging from 75 per cent of teachers in grammar schools to some 4 per cent in primary schools. About 33 per cent of teachers in establishments of further education were graduates, and graduates also accounted for more than 60 per cent of teachers in direct grant grammar schools.

But the figures showing the wastage of qualified teachers are dismally high. Thus between 1965 and $1966,9,000$ qualified men teachers entered maintained 
primary and secondary schools, and in the same period 7,000 left the schools. Wastage was greatest among those under thirty, and was also high among untrained graduates under 25. The comparable figure for women was even higher-representing 13 per cent of those qualified and in service, and wastage was again high among untrained graduates. Significant proportions of this wastage could, however, be attributed to transfer from one teaching establishment to another, although among qualified women teachers only 1,000 out of a total of 20,000 transferred in this way.

NUMBERS OF STUDENTS IN COLLEGES OF EDUCATION AND UNIVERSITY DEPARTMENTS OF EDUCATION (other than supple. mentary courses)

Numbers of students

In university

departments of

education

In colloges of

$1956-57$ Oct 1962 Oet 1964 Oet 1965 Oct 1966

education

$\begin{array}{rrrrr}2,512 & 3,260 & 3,739 & 3,695 & 3,192 \\ 26,039 & 47,682 & 62,112 & 72,856 & 84,911\end{array}$

The last page in the report lists the salaries of teachers in colleges of education at March 31, 1966. For male graduates the average salary was $\mathfrak{f 1 , 5 3 9}$

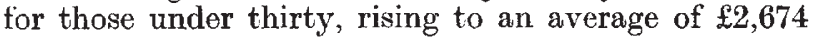
for those aged 60 and over; figures for women graduates were very similar. Male non-graduates received some $£ 100$ less under the age of 30 , and about $£ 140$ less over the age of 60 .

\section{Change on Blood Tests}

THe British Home Office seems to be modifying slightly its attitude to the tests by which motorists in Britain can now be convicted of driving under the influence of alcohol. A recent paper in Nature by Professor J. B. Payne, Dr D. W. Hill and Mr D. G. L. Wood of the Royal College of Surgeons $(21 \%, 963 ; 1968)$ suggests that the methods used by police authorities for carrying out the tests are far from accurate. The method by which the amount of alcohol in the bloodstream is estimated from the amount in the urine seems particularly suspect. So far the Home Office has not been forced to act, because no motorist accused of driving under the influence of drink has quoted Professor Payne's work in his defence.

Although the Home Office has not changed its views on the urine test, there does seem to have been a shift of emphasis in the blood tests. Originally, after advice from the medical associations, police surgeons were advised to take small samples of capillary blood for use in the test, although it was also open to them to take venous blood if they preferred. The work at the Royal College of Surgeons suggests that the latter is likely to give more accurate results, because of the way in which the alcohol tends to become more concentrated in the plasma than in the red blood cells. Blood taken from capillaries can often contain more plasma than blood from veins, so that the capillary method can give anomalously high readings, with the possibility of conviction for a driver who is in fact under the limit.

The Home Office has now sent a circular to police authoritics pointing out that it is within their discretion to take venous rather than capillary blood. The police authorities are advised by the Home Office always to have available a supply of syringes with which venous blood samples can be taken. The motorist can still decide which method he prefers, though the doctor will be at liberty to advise the syringe method if he thinks fit. The circular also points out that the motorist has the right to keep a sample of his own blood for independent analysis, and that these samples should be sealed, stored in a cool place, and analysed with the minimum of delay.

So far, this is no more than a recommendation from the Home Office to the police authorities. Both methods of taking blood are still legal, and the circular says nothing of the inaccuracies of the urine test. But in the event of a driver being acquitted because of the inaccuracies which Professor Payne and his colleagues have discovered, the Home Office would doubtless have to act very much more decisively. Whether the work provides new grounds for appeal for those already convicted under the existing law has yet to be tested, but there is an urgent need to clarify the situation. Sooner or later the Home Office will be forced to set about the task.

\section{Preserving the Bastard Toadflax}

The Nature Conservancy has announced two new nature reserves and an extension to another, bringing the total number of national nature reserves to 124 , covering 257,239 acres.

One of the new reserves is in the central part of the range of chalk hills forming the northern scarp of the Vale of Pewsey seven miles south-west of Marlborough. It is a fine example of unreclaimed chalk downland, and it has long been known to botanists and entomologists for its rich plant and insect life. Extending from Milk Hill in the west to Knap Hill in the east, the reserve covers 188 acres and it has been established by agreement with New College, Oxford, and the agricultural tenant. The summit of Milk Hill $(964 \mathrm{ft})$ is the highest point in Wiltshire. Examples of plants found in the reserve are round-headed rampion, field fleawort, bastard toadflax and several orchids. The Chalk Hill Blue and the Brown Argus are two of the butterflies found. There are also several features of archaeological and historical interest. One of the best examples of a neolithic causeway camp lies on Knap Hill, and there is also a chambered long barrow known as Adams Grave on Walkers Hill.

The other new reserve is at Fbbot Gorge, Somerset,

\section{Sorry, for copyright \\ reasons some images on this page may not be available online}

North part of Hartland Moor, Isle of Purbeck (Crown copyright). 